The Research Journal of the Costume Culture

[Original Article]
pISSN 1226-0401

eISSN 2383-6334

RJCC Vol.25, No.3, pp.327-339, June 2017

https://doi.org/10.7741/rjcc. 2017.25.3.327

\title{
A hierarchical model of self-determined motivation for thrift shopping behavior
}

\author{
Keunyoung $\mathrm{Oh}^{\dagger}$ and Yun-Jung Choi ${ }^{*}$ \\ Fashion and Textile Technology, SUNY Buffalo State, USA \\ Human Ecology, Fashion and Textiles, SUNY Oneonta, USA*
}

\begin{abstract}
A consumer is an individual entity with various motivations. This study is intended to incorporate a hierarchical structure of motivation to understand self-determined motivation for purchasing secondhand merchandise at thrift stores. A conceptual model adopted from Cadwallader et al. (2010)'s comprehensive model of motivation used in a marketing context was developed to investigate motivational process in secondhand merchandise shopping. The conceptual model includes the three levels of motivational structure - the global, contextual (environmental concern and frugality), and situational motivation. A series of the causal relationships among the three levels of self-determined motivations and buying intention to shop at thrift stores were hypothesized. A total of 219 respondents from two different northeastern state universities in the U.S. completed a self-administered survey. The results indicated that secondhand merchandise shopping is well explained in the hierarchical structure of self-determined motivation where the global motivation had a positive impact on the contextual motivations regarding environmental concern and frugality. Of the two contextual motivations, only environmental concern had a positive impact on situational motivation for shopping at thrift stores. Finally, the situational motivation positively influenced the intention to shop at thrift stores. The results of this model suggest that the hierarchical structure of self-determined motivation would be a very useful framework to understand consumer behavior for apparel shopping. Also, further research can be done to identify other contextual motivational factors to understand consumer motivation for shopping at thrift stores.
\end{abstract}

Keywords: hierarchy of self-determined motivation, thrift shopping

Received May 24, 2017

Revised June 14, 2017

Accepted June 19, 2017

${ }^{\dagger}$ Corresponding author

(ohk@buffalostate.edu)

ORCID

Keunyoung Oh

http://orcid.org/0000-0003-0672-4344

Yun-Jung Choi

http://orcid.org/0000-0001-7234-2235

\section{Introduction}

A great deal of research has long devoted to the utilitarian and hedonic constructs of purchasing motivation within the field of consumer behavior, even in the online shopping environments (Bridges \& Florsheim, 2008). Previous research indicates that consumers in shopping desire to maximize and negotiate values (Babin, Darden, \& Griffin, 1994). Consumers also wish to experience fantasy, excitement, and fun in the event of shopping (Arnold \& Reynolds, 2003; Yim, Yoo, Sauer, \& Seo, 2014). It is necessary to uncover the reasons of purchasing activities in under- 
standing of consumer purchasing behavior. Nevertheless, human motivation is complicated and multifaceted (Mitchell, 1982; Reiss, 2012). In this study, the researchers launch a more complementary approach to understand the full array of consumer motivation in the thrift-shopping context.

Human motivation has always been an issue of concern in a society and in human lives (Maehr \& Braskamp, 1986). A consumer is an individual entity with various motivations. This study is intended to apply a hierarchical structure of self-determined motivation: global, contextual, and situational (Guay, Mageau, \& Vallerand, 2003), to understand self-determined motivation for shopping secondhand merchandise at thrift stores. Even though there is a growing acknowledgement that people do shop secondhand merchandise at thrift stores (Bardhi, 2003; Christiansen \& Snepenger, 2005; Darley \& Lim, 1999; Reeger, 2005), there has been a relative neglect of consumer motivational processes in the context of thrift shopping environment.

Self-determination is defined as "both the attitudes which lead people to define goals for themselves and to their ability to take the initiative to achieve them" (Ward, 1988, p. 2). Self-determination theory represents a coherent theoretical point that enhances our understanding of motivational processes (Vallerand, 2000). The study aims at verifying the impact of selfdetermined motivational variables on consumer purchasing behavior at thrift stores in the framework of the hierarchical structure of self-determined motivation.

\section{Literature Review}

\section{Thrift shopping}

Thrift shopping is defined as "the buying of previously owned products" (Christiansen \& Snepenger, 2005, p. 323). Consumers shop pre-owned products in a number of various retail settings including renowned charitable non-profit organizations such as Salvation Army and Goodwill industries (Bardhi, 2003;
Christiansen \& Snepenger, 2005). Consumers discover potential and hidden values in a thrift store (Han, 2013). It is proposed that 'thrift shopping' is a unique and considerable paradigm in which consumers are involved in a purchasing process with inherent motivations.

Prior research has tended to define the factors that motivate consumers to shop in thrift stores. Using the data from respondents living in a Midwestern Standard Metropolitan Statistical Area (SMSA), Yavas and Riecken (1981) examined consumer-shopping motives at Goodwill stores. The results showed that price was the major motive for the consumers when shopping at Goodwill. Obviously, however, 'adventure', 'treasure hunting' and 'quality' were also appealing considerations for a large number of consumers when shop secondhand merchandise at Goodwill (Yavas \& Riecken, 1981). Also, Roux (2006) reported that consumers who expressed favorable attitudes toward the reuse of pre-owned clothing were seeking for uniqueness, financial benefits through bargaining, and also nostalgic experience of the past through secondhand clothes wearing and purchasing. According to Roux (2006), some consumers, however, with negative and rejection attitudes toward secondhand clothing exhibited strong fears of incorporating a dishonored image of the former owner.

While many studies discussed the economic and utilitarian values on thrift shopping, Bardhi and Arnould (2005) identified that consumers shop for both 'thriftiness' and 'fun' in the thrift shopping context. Consumers embrace hedonic benefits in the thrift shopping environment. Consumers feel excited, pleasant, thrilled, and fun while thrift shopping (Bardhi \& Arnould, 2005). It is evident that economical and pleasure benefits are co-living in the thrift shopping process (Bardhi, 2003; Bardhi \& Arnould, 2005). The existing literature on thrift purchasing well reveals the factual reasons consumers shop in thrift stores. However, no previous research has dedicated to incorporate diverse approaches into consumer thrift shopping behavior. 
This study seeks evidence for hierarchical relationships among various consumer motivations guided by self-determination theory. Self-determination theory is well posited to explain various consequences that derive from the different forces of motivation (Pelletier, 2002). It is proposed that self-determined motivations can explain how consumers engage and get motivated in the thrift-shopping environment.

\section{Self-determination theory}

Self-determination theory concerns with human motivation and explains the processes through which unenthusiastic or passive behaviors can become autonomous or intrinsically motivated (Ryan \& Deci, 2000). Self-determination refers to "the attitudes which lead people to define goals for themselves and to their ability to take the initiative to achieve them" (Ward, 1988, p. 2). Ryan and Deci (2000)'s self-determination continuum reflects three distinct motivational types: Amotivation, Extrinsic motivation, and Intrinsic motivation. Amotivation refers to "the state of lacking the intention to act" (Ryan \& Deci, 2000, p. 72). Amotivated individual often holds feelings of reluctance to act, unsatisfied, and uncontrollability (Gillet, Berjot, \& Gobancé, 2009; Ryan \& Deci, 2000). Extrinsic motivation refers to "the performance of an activity in order to attain some separable outcome" (Ryan \& Deci, 2000, p. 71). Extrinsic motivation is associated with engagement in an activity that possibly leads to external rewards or expected appraisal (Amabile, 1997; Vlachopoulos, Karageorghis, \& Terry, 2000). Extrinsic motivation is associated with engagement in an activity that possibly leads to external rewards or expected appraisal whereas intrinsically motivated behaviors are driven by enjoyment, interest, challenge, curiosity, and satisfaction (Vlachopoulos et al., 2000). Extrinsically motivated behaviors can be categorized further by the level of being autonomous (Ryan \& Deci, 2000).

Intrinsic motivation refers to "doing an activity for the inherent satisfaction of the activity itself" (Ryan \& Deci, 2000, p. 71). Intrinsically motivated behavior is driven by enjoyment, interest, challenge, curiosity, and satisfaction (Amabile, 1997; Vlachopoulos et al., 2000). Self-determined behavior is led by the intrinsic motivation while amotivation results in not acting at all or acting without intent (Ryan \& Deci, 2000). It is proposed that a self-determined consumer would shop voluntarily and responsibly seek the inherent gratification of the activity. De Young (2000) suggested that proenvironmntal behavior is highly associated with intrinsic motivation.

The diminishing negative images of secondhand merchandise and the wide interest in environmentally responsible activities like recycling led average consumers to shop at thrift stores (Darley \& Lim, 1999). The more self-determined motivations are expected to bring more healthy and encouraging outcomes (Vlachopoulos et al., 2000). The intrinsic motivation might shape consumer-shopping behavior in thrift stores.

Not many studies have applied self-determination theory in the marketing and consumer behavior disciplines especially related to apparel consumption. Previously, Cadwallader, Jarvis, Bitner, and Ostrom (2010) used and tested Vallerand's hierarchical model of self-determination theory in a marketing strategy implementation in the context of service. Cadwallader and his colleagues (2010) studied employee motivational processes to engage in service innovation by adapting and extending the work of Ryan and Deci (2002) and Vallerand (2000). Their research supported the view of hierarchical structure of motivation. In this study, a conceptual model was developed by adopting Cadwallader et al. (2010)'s comprehensive model of self-determined motivation in marketing to investigate consumer motivational processes in the context of thrift shopping. This study seeks evidences for hierarchical relationships among the consumer motivations for thrift shopping. The perspective of the hierarchical model of self-determined motivation would help enhance the understanding of complicated and multifaceted consumer shopping motivational processes in the context of thrift retailing environment. 


\section{Hierarchy of self-determined motivations}

The model reflects three levels of motivational structure - the global, contextual, and situational motivation levels (Fig. 1). Global motivation, which posits on top level of the hierarchy, refers to "a broad disposition to engage in activities with an intrinsic or extrinsic orientation" (Vallerand, 2000, p. 313). Global motivation relates to individual personality and differences when performing an activity such as 'practical', 'social', 'careless'.

Contextual motivation, which posits on the second level of hierarchy, corresponds to "motivational orientations that are specific to various contexts" (Vallerand, 2000, p. 313). Contextual motivation is associated with motivation toward life sphere contexts such as education, work, religion, and social relationships (Cadwallader et al., 2010; Vallerand, 2000). In this study, 'environmental concern' and 'frugality' are included to test consumer contextual motivation.

\section{Environmental concern for contextual motivation}

Human motivation produces psychological and behavioral outcomes (Ryan \& Deci, 2002; Vallerand, 2000). Environmentally conscious consumers are described as individuals who concern the possible harmful consequences of their behaviors and purchase deci-

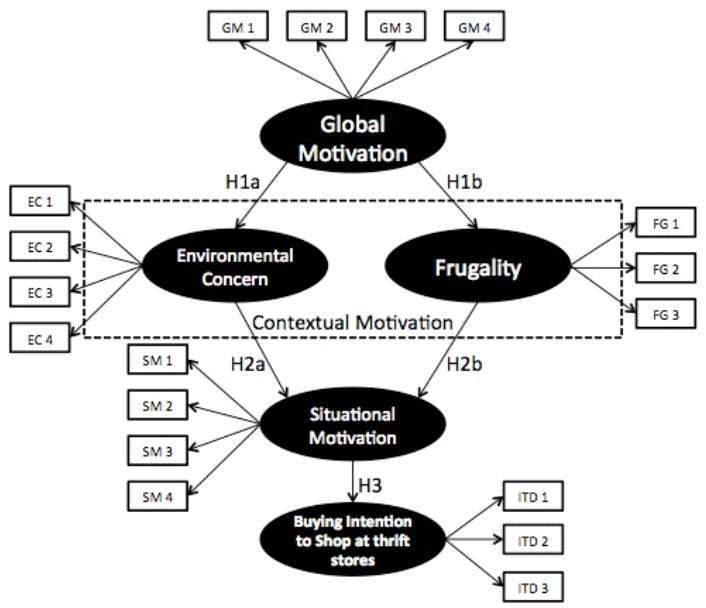

<Fig. 1> The hierarchical structure of self-determined motivation for thrift shopping sions to environment and well-being of other individuals (Bourgeois \& Barnes, 1979; Shim, 1995).

Environmental concerned consumers take responsibility for their shopping activity desiring that their earth-friendly purchasing and consumption behavior has a positive influence on the environment (Minton $\&$ Rose, 1997). Purchasing environment-friendly products seems like an attempt for consumers to express their understanding that buying and consumption carry consequences. It is predicted that consumer global motivation affects consumer's choice where to shop and what to buy.

\section{Frugality for contextual motivation}

Motivation is concerned with psychological processes that lead for an individual to engage in global directed actions and behaviors (Mitchell, 1982). Being frugal is a disciplined life style in which a consumer is prudent in buying and using products and services to achieve longer-term goals in the future (De Young, 1996, 2000; Lastovicka, Bettencourt, Hughner, \& Kuntze, 1999). Consumer motivation regarding to frugality might be related to their global motivation. As Lastovicka and his colleagues (1999) suggested, the concept of frugality may play an important role for understanding consumer behavior in the context of thrift shopping. Reviews on environmental concerns and frugality as contextual motivation generated the following hypotheses.

H1a: Consumer global motivation will have a positive influence on consumer contextual motivation concerning environmental concern

H1b: Consumer global motivation will have a positive influence on consumer contextual motivation concerning frugality

\section{Situational motivation}

Situational motivation, which posits on the last level of hierarchy, refers to "the here and now of motivation" (Vallerand, 2000, p. 313). Situational motivation is concerned with engaging in a specific activity 
(Cadwallader et al., 2010) such as working at a department store or recycling plastic bottles. Situational motivation is at work when an individual is currently involving in an activity (Guay, Vallerand, \& Blanchard, 2000). Thus, Guay et al.(2000) argue that situational motivation is particularly useful when explaining a person's current motivational processes.

One of the key meanings for thrift stores is to serve to recycle merchandise (Horne, 2000). Consumers might be more willing to shop at thrift stores when they are more engaged with various recycling activities. Consumers might concern with environment and sustainability and be interested in integrating these concerns into their shopping behavior. It is shown that consumers' concern to environment influences product and store choice (Hyllegard, Ogle, \& Dunbar, 2006). It is proposed that contextual motivation concerning environmental concern shapes consumer situational motivation for thrift shopping.

Humans are a calculating egoism in nature and act to maximize their well-being (Parsons, 1964). Consumer contextual motivation related to frugality might lead consumers to behave in a rational way to maximize and negotiate their utility in thrift shopping environments. Consumers' frugality might play a role of choosing 'right' or 'appropriate' place to shop for the individual consumer. In addition, frugal consumers are carefully calculating when spending and are interested in optimization of limited sources (Wherry, 2008). Individuals 'choose' to be frugal consumers to demonstrate their character and values (Wherry, 2008). Consumers might choose to shop at thrift stores to assure their valued consumption behavior. It is proposed that consumers who are motivated to be frugal are likely to be more motivated to engage in thrift shopping.

$\mathrm{H} 2 \mathrm{a}$ : Consumer contextual motivation concerning environmental concern will have a positive influence on consumer situational motivation to engage in thrift shopping.

$\mathrm{H} 2 \mathrm{~b}$ : Consumer contextual motivation concerning frugality will have a positive influence on consumer situational motivation to engage in thrift shopping.

H3: Situational motivation to engaging in thrift shopping will have a positive influence on consumer shopping intention at thrift stores.

\section{Method}

\section{Measures}

A self-administered survey was used to collect the data. The questionnaire was designed to measure hierarchical relationships among motivational variables of consumer thrift shopping behavior. The final questionnaire consisted of five major sections: global motivation, contextual motivation, situational motivation, intention to shop in thrift stores, and demographic questions.

The Global Motivation Scale was used to measure global motivation including four sets of seven selfdetermined motivations. The measurement items were used to assess how individual differences influence their perceptions and behaviors when they do things in general. An example item reads, "In general, I do things for the enjoyment of acquiring new knowledge".

In the section two, contextual motivation regarding environmental concern was measured by four sets of six self-determined motivations such that "I practice environment friendly activities because I feel a lot of personal satisfaction while engaging in environment friendly activities". Contextual motivation regarding frugality was measured by three sets of five selfdetermined motivations. Environmental concern items and frugality items were modified from measures of Mallett, Kawabata, Newcombe, Otero- Forero, and Jackson (2007). Respondents were asked to indicate what extent each of the items corresponds to one of the reasons for which they were engaging in environment friendly activities and were practicing (being) frugality. The Situational Motivation Scale consisting of 22 items was used to measure situational motivation to shop at thrift stores. Respondents were asked to 
rate the statements that best describe the reason why they are engaged in thrift shopping. One example item reads: "Because I think that thrift shopping is interesting".

The four motivational variables - global motivation, contextual motivation regarding environmental concerns, contextual motivation regarding frugality, and situational motivation regarding shopping at thrift stores - were all composite scales representing the level of self-determined motivation on the selfdetermination continuum (Guay et al., 2003). The levels of self-determined motivation consist of a summation of specifically weighted scores; therefore, in this study, the subsets of the motivational scales were combined to generate the composite motivational indices that were fed into the structural equation model estimation. The weighting schema and the calculation formulas were all used in the previous studies and have been well received by the researchers in this type of research (i.e., Cadwellader, et al., 2010). All items were measures on a seven-point Likert scale. The statements used to measure the hierarchical structure of self-determined motivation are found in 〈Table 1〉.

The section four included nine items developed by researchers to ask thrift shopping experience and intentions to purchase secondhand merchandise. Three statements were used to assess thrift shopping intention. Respondents also rated their degree of shopping intention at thrift stores on a seven-point Likert-type scale $(1=$ Strongly disagree; $7=$ Strongly agree). One example item reads "I intend to buy secondhand merchandise at thrift stores in the future".

Demographic questions in the final fifth section of the questionnaire were included to interpret the respondents' responses on other questions. An IRB approval was obtained from both universities where data collection was conducted.

\section{Procedure}

Participants in this study were college students attending two four-year state universities located in the northeastern region of the US. Given the speedy growth of young consumers in thrift shopping (Hankin, 2016), it is appropriate to use a college student sample for this study. A self-administrated survey was used to collect data on intrinsic and extrinsic motivations at the global, contextual, and situational levels and thrift shopping behavior among college students in two NE state universities. A total of 219

$<$ Table 1> The statements used in the hierarchical structure of self-determined motivation

\begin{tabular}{|c|c|}
\hline \multicolumn{2}{|r|}{ Intention to shop at thrift stores } \\
\hline 1 & I intend to buy apparel goods at thrift store in the future. \\
\hline 2 & I will try to buy apparel goods at thrift stores in the future. \\
\hline 3 & I will recommend others to buy apparel goods at thrift stores. \\
\hline \multicolumn{2}{|r|}{$\begin{array}{c}\text { Global Motivation Scale } \\
\text { "In general, (at home, school, work, anytime), I do things } \cdots . . . . "\end{array}$} \\
\hline 1 & In order to feel good. \\
\hline 2 & Because I enjoy making interesting discoveries. \\
\hline 3 & Because of the enjoyment I feel as I become more and more skilled. \\
\hline 4 & In order to become the person I aim to be. \\
\hline 5 & Because I would beat myself up for not doing them. \\
\hline 6 & Because I don't want to disappoint certain people. \\
\hline 7 & Even though I do not see the benefit in what I might be doing. \\
\hline 8 & Because of the sense of well-being I feel while I am doing them. \\
\hline 9 & For the enjoyment of acquiring new knowledge. \\
\hline 10 & For the enjoyment I feel mastering what I am doing. \\
\hline 11 & Because I choose them as means to attain my objectives. \\
\hline 12 & Because otherwise I would feel guilty for not doing them. \\
\hline
\end{tabular}


$<$ Table 1> Continued

13 Because I want to be viewed more positively by certain people.

14 Although it does not make a difference whether I do them or not.

15 For the enjoyable sensations I feel while I am doing them.

16 For the enjoyment of learning new, interesting things.

17 Because of the satisfaction I feel in trying to excel in what I do.

18 Because I choose to do them in order to attain what I desire.

19 Because I force myself to do them.

20 In order to show others what I am capable of doing.

21 Even though I do not have a good reason for doing them.

22 For the enjoyable feelings I experience.

23 For the enjoyment of learning different, interesting facts.

24 Because of the enjoyment I feel while outdoing myself.

25 Because I choose to invest myself in what is important to me.

26 Because I would feel bad if I did not do them.

27 In order to attain prestige.

28 Even though I believe they are not worth the trouble.

Contextual Motivation - Environment Friendly Activities

Why do you practice Environment Friendly Activities?

1 For the excitement I feel when I am really involved in the activity.

2 Because it's part of the way in which I've chosen to live my life.

3 Because it is a good way to learn lots of things which could be useful to me in other areas of my life.

4 Because it allows me to be well regarded by people that I know.

5 Because it is absolutely necessary to do environment friendly activities if one wants to be in mental shape.

6 I don't know anymore: I have the impression of being incapable of succeeding in environment friendly activities.

7 Because I feel a lot of personal satisfaction while engaging in environment friendly activities.

8 Because it is an extension of me.

9 Because it is one of the best ways I have chosen to develop other aspects of my life.

10 Because I must do environment friendly activities to feel good about myself.

11 For the prestige of being an individual who cares for environments.

12 I don't know if I want to continue to invest my time and effort as much in environment friendly activities anymore

13 For the enjoyment I experience while I am practicing in environment friendly activities.

14 Because participation in environment friendly activities is consistent with my deepest principles.

15 Because it is one of the best ways to maintain good relationships with my friends.

16 Because I would feel bad if I was not taking time to do it.

17 People around me think it is important to be in mental shape

18 It is not clear to me anymore; I don't really think my place in environment friendly activities

19 For the pleasure of discovering new practices benefiting environments.

20 Because participation in environment friendly activities is an integral part of my life.

21 I feel that participating in environment friendly activities will make me a more valuable citizen.

22 Because I must do environment friendly activities regularly.

23 To show others how good I am at environment friendly activities.

24 I don't seem to be enjoying environment friendly activities as much as I previously did. Contextual Motivation - Frugality

Why are you practicing frugality?

\begin{tabular}{l|l}
\hline 1 & The sense of achievement I experience while practicing frugality in a personal and unique way. \\
\hline 2 & $\begin{array}{l}\text { I chose to practice frugality because it allows me to attain some important goals, while at the same time allowing } \\
\text { me to respect other aspects of my life. }\end{array}$ \\
\hline 3 & I personally feel that I really ought to be frugal and I would be disappointed otherwise. \\
\hline 4 & It allows me to save money. \\
\hline 5 & I don't know; I have the impression that I don't have what it takes to practice frugality well. \\
\hline 6 & The excitement I feel when I am really involved in frugality. \\
\hline
\end{tabular}


$<$ Table 1> Continued

\begin{tabular}{|c|c|}
\hline 7 & This is the way of living I prefer in order to pursue my life goal. \\
\hline 8 & I really want to be successful in my life and I would be ashamed otherwise. \\
\hline 9 & For the saving. \\
\hline 10 & I don't know; I just cannot manage to practice frugality well. \\
\hline 11 & The enjoyment I feel in having exciting experiences by practicing frugality. \\
\hline 12 & It is the way of living I chose to live towards fulfilling my life plan. \\
\hline 13 & Being frugal is my life and I don't want to fail. \\
\hline 14 & Frugality provides security. \\
\hline 15 & I don't know; I can't seem to achieve the goals that I set for myself in practicing frugality. \\
\hline & Situational Motivation - Shopping at thrift stores \\
\hline 1 & Because I think that shopping at thrift stores is interesting. \\
\hline 2 & Because I am shopping at thrift stores for my own good. \\
\hline 3 & Because I am supposed to shop at thrift stores. \\
\hline 4 & There may be good reasons to shop at thrift stores, but personally I don't see any \\
\hline 5 & Because I think that shopping at thrift stores is pleasant. \\
\hline 6 & Because I think that shopping at thrift stores is good for me. \\
\hline 7 & Because shopping at thrift stores is something that I have to do. \\
\hline 8 & I do (may) shop at thrift stores; but I am not sure if it is worth it. \\
\hline 9 & Because shopping at thrift stores is fun. \\
\hline 10 & By personal decision. \\
\hline 11 & Because I don't have any choice. \\
\hline 12 & I don't know; I don't see what shopping at thrift stores brings me. \\
\hline 13 & Because I feel good when shopping at thrift stores. \\
\hline 14 & Because I believe that shopping at thrift stores is important for me. \\
\hline 15 & Because I feel that I have to shop at thrift stores. \\
\hline 16 & I do (may) shop at thrift stores; but I am not sure it is a good thing to pursue it \\
\hline 17 & I believe in being careful in how I spend my money. \\
\hline 18 & I discipline myself to get the most from my money. \\
\hline 19 & There are things I resist buying today so I can save for tomorrow. \\
\hline 20 & Making better use of my resources makes me feel good. \\
\hline 21 & If you take care of your possessions, you will definitely save money in the long run. \\
\hline 22 & I am willing to wait on a purchase I want so that I can save money. \\
\hline
\end{tabular}

students completed the questionnaire with extra points given to them as an incentive. Participants were informed of the purpose of the study and were expected to complete the survey in 25 minutes. The majority were females $(79.4 \%)$ and $79 \%$ said that they have shopped at thrift stores. Their age ranged from 18 to 30 years old and $66.4 \%$ were working at least 10 hours a week. Data analysis was conducted in maximum likelihood structural equation modeling using AMOS 18.

\section{N. Results and Discussions}

Data analysis was conducted in maximum likeli- hood structural equation modeling using AMOS 18. The fit of the CFA model is acceptable: $\chi_{(123)}{ }^{2}=$ $174.41(p=.002), \mathrm{CFI}=.98, \mathrm{TLI}=.95, \mathrm{IFI}=.98, \mathrm{GFI}=.92$, $\mathrm{AGFI}=89$, RMSEA=.04. All factor loadings were positive and significant providing evidence of convergent validity (Table 2). The overall structural model fit the data well: $\chi_{(127)}{ }^{2}=177.56(p=.002), \mathrm{CFI}=.98$, $\mathrm{TLI}=.98, \mathrm{IFI}=.98, \mathrm{GFI}=.92, \mathrm{AGFI}=.89, \mathrm{RMSEA}=.04$. All the structural parameters were significant except for the path from frugality (contextual motivation) to situational motivation. The results of the hypotheses testing can be found in 〈Table 3〉. Global motivation was positively related to contextual motivations regarding environmental concern and frugality. The re- 
sults illustrate that individual general differences, such as perceptions and personal traits when engaging in activities that can have a strong impact on various

$<$ Table 2> Maximum likelihood estimates - CFA factor loadings

\begin{tabular}{|c|c|c|}
\hline $\begin{array}{c}\text { Measurement } \\
\text { variables }\end{array}$ & Latent variables & $\begin{array}{c}\text { Standardized } \\
\text { estimates }\end{array}$ \\
\hline GM1 & Global motivation & $.728^{* * *}$ \\
\hline GM2 & Global motivation & $.794^{* * *}$ \\
\hline GM3 & Global motivation & $.719^{* * *}$ \\
\hline GM4 & Global motivation & $.790^{* * *}$ \\
\hline $\mathrm{EC} 1$ & Environmental motivation & $.680^{* * *}$ \\
\hline $\mathrm{EC} 2$ & Environmental motivation & $.681^{* * *}$ \\
\hline $\mathrm{EC} 3$ & Environmental motivation & $.664^{* * *}$ \\
\hline $\mathrm{EC} 4$ & Environmental motivation & $.652^{* * *}$ \\
\hline FG1 & Frugality & $.669^{* * *}$ \\
\hline FG2 & Frugality & $.692^{* * *}$ \\
\hline FG3 & Frugality & $.685^{* * *}$ \\
\hline SM1 & Situational motivation & $.925^{* * *}$ \\
\hline SM2 & Situational motivation & $.801^{* * *}$ \\
\hline SM3 & Situational motivation & $.912^{* * *}$ \\
\hline SM4 & Situational motivation & $.792^{* * *}$ \\
\hline ITD1 & Intention to shop & $.944^{* * *}$ \\
\hline ITD2 & Intention to shop & $.969^{* * *}$ \\
\hline ITD3 & Intention to shop & $.912^{* * *}$ \\
\hline
\end{tabular}

*** Significant at $p<.001$ contextual motivations. Importantly, global self-determined motivations are incorporated with consumer specific orientations in different contexts. Contextual motivation for environmental concern was positively related to situational motivation to shop at thrift stores. However, frugality was not significantly related to situational motivation. This finding can be explained by the thought that the frugality is possibly influenced by the demographic dimensions, especially age. This result is consistent with the previous research of Pepper, Jackson, and Uzzell (2009) who found that frugal consumer behavior is positively correlated with age. Consequently, the hierarchy of self-determined motivation was partially supported. Self-determined motivation for thrift shopping had a significantly positive relationship to intention to shop at thrift stores. The results of this model suggest that the hierarchical structure of self-determined motivation would be a very useful framework to understand consumer behavior for apparel shopping.

\section{Conclusions}

The purpose of this study was to apply the hierarchical structure of self-determined motivation to understand consumer motivation for thrift shopping. The present study, to our knowledge, is the first to reveal that the hierarchical model of self-determined motivations explains consumer behavior well in the context of thrift retailing environments. Environmental concerns and frugality were included as contextual

$<$ Table 3> Structural model estimates

\begin{tabular}{c|c|c}
\hline Hypothesis & \multicolumn{1}{|c}{ Hypothesized paths } & Standardized path coefficient \\
\hline H1a & Global motivation $\rightarrow$ Environmental concerns & $0.655^{* * *}$ \\
\hline H1b & Global motivation $\rightarrow$ Frugality & $0.349^{* * *}$ \\
\hline H2a & Environmental concerns $\rightarrow$ Situational motivation & $0.532^{* * *}$ \\
\hline H2b & Frugality $\rightarrow$ Situational motivation & 0.065 \\
\hline H3 & Situational motivation $\rightarrow$ Buying intention at thrift stores & $0.794^{* * *}$ \\
\hline
\end{tabular}

*** Significant at $p<.001$ 
motivation that is influenced by global motivation and have influence on situational motivation for thrift shopping. A modified hierarchical structure model of self-determined motivation for thrift shopping was developed and examined to test the proposed hypotheses. A total of 219 undergraduate students were recruited for this study. The results of structural equation modeling supported the proposed hypotheses except for one suggesting a possible positive influence of contextual motivation for frugality on situational motivation for thrift shopping. Consumer's global motivation (amotivation - extrinsic motivation - intrinsic motivation) influenced both contextual motivation that were measured as being concerned about environments and practicing frugality. Consumers are motivated intrinsically at their daily activities tend to enjoy their proenvironmental activities and showed greater concerns for environments. They also actively practice frugality for fun and inner satisfaction. Consumers who are more intrinsically motivated for participating in proenvironmental activities tend to form a very positive stance on thrift shopping. Situational motivation for thrift shopping is a good indicator for consumers' intention to shop at thrift stores and to buy secondhand merchandise. The results of this study proved that the hierarchical structure of self-determined motivation could be applied to understand consumerpurchasing behavior given that consumer motivation can be a multi-faceted concept both conceptually and structurally. Consumers interested in shopping for secondhand merchandise are not just motivated for frugality rather they are actively seeking ways to practice environment friendly shopping activities.

\section{Implications for Further Research}

Several areas require further attention and academic research. First, the results of the study speak to the importance of examining how the self-determined motivations in a hierarchical structure affect U.S. consumer thrift shopping behavior. Self-determined thrift shopping motivations in other social and cultural con- texts should lead to meaningful research. Specifically, concerns about environments have been raised in South Korea (PESTLE country analysis report, 2016). It would be of value to analyze the effect of the global, contextual, and situational motivations on the decision to shop at thrift stores in South Korea.

Second, in this study, the model developed enabled us to measure two contextual motivations: environmental concern and frugality on the situational motivation. Future research efforts can be made to explore possible other contextual motivational factors to better understand the dynamics of consumer thrift shopping behavior. Other demographic groups need to be studied as well.

Third, this research revealed the impact of selfdetermined motivational variables on consumer buying intentions to shop at thrift stores. Consumer's socially responsible consumptions such as clothing discard behaviors, donations, or recycling might be explained by the level of self-determined motivation especially with intrinsic motivation. The research will provide an insight to understand how self-determination is associated with psychological well- being and growth which is related to intrinsic motivation (Ryan \& Deci, 2000).

This study highlighted the underlying role of selfdetermined consumer motivations in the thrift retailing settings. It is plausible that consumers pursue intrinsically satisfied outcomes in today's ever-dynamic retailing environment. Marketers and retailers could strive to create unique online and offline shopping environments for consumers to meet their intrinsic motivations such as enjoyment, challenge and curiosity. Creative retailing environments might inspire intrinsically motivated consumers to fulfill their need and desires while shopping regardless the types or nature of retailing.

\section{References}

Amabile, T. M. (1997). Motivating creativity in organizations: On doing what you love and loving what 
you do. California Management Review, 40(1), 39-58. doi:10.2307/41165921

Arnold, M. J., \& Reynolds, K. E. (2003). Hedonic shopping motivations. Journal of Retailing, 79(2), 77-95. doi:10.1016/S0022-4359(03)00007-1

Babin, B. J., Darden, W. R., \& Griffin, M. (1994). Work and/or fun: Measuring hedonic and utilitarian shopping value. Journal of Consumer Research, 20(4), 644-656. doi:10.1086/209376

Bardhi, F. (2003). Thrill of the hunt: Thrift shopping for pleasure. Advances in Consumer Research, 30, 375-376.

Bardhi, F., \& Arnould, E. J. (2005). Thrift shopping: Combining utilitarian thrift and hedonic treat benefits. Journal of Consumer Behaviour, 4(4), 223-233. doi:10.1002/cb.12

Bourgeois, J. C., \& Barnes, J. G. (1979). Viability and profile of the consumerist segment. Journal of Consumer Research, 5(4), 217-228. doi:10.1086/ 208734

Bridges, E., \& Florsheim, R. (2008). Hedonic and utilitarian shopping goals: The online experience. Journal of Business Research, 61(4), 309-314. doi:10.1016/j.jbusres.2007.06.017

Cadwallader, S., Jarvis, C. B., Bitner, M. J., \& Ostrom, A. L. (2010). Frontline employee motivation to participate in service innovation implementation. Journal of the Academy of Marketing Science, 38(2), 219-239. doi:10.1007/s11747-009-0151-3

Christiansen, T., \& Snepenger, D. J. (2005). Information sources for thrift shopping: Is there a "thrift maven"?. Journal of Consumer Marketing, 22(6), 323-331. doi:10.1108/07363760510623911

Darley, W. K., \& Lim, J.-S. (1999). Effects of store image and attitude toward secondhand stores on shopping frequency and distance traveled. International Journal of Retail \& Distribution Management, 27(8), 311-318. doi:10.1108/09590559910288596

De Young, R. (1996). Some psychological aspects of reduced consumption behavior: The role of intrinsic satisfaction and competence motivation.
Environment and Behavior, 28(3), 358-409. doi: 10.1177/0013916596283005

De Young, R. (2000). New ways to promote proenvironmental behavior: Expanding and evaluating motives for environmentally responsible behavior. Journal of Social Issues, 56(3), 509-526. doi:10.1111/0022-4537.00181

Gillet, N., Berjot, S., \& Gobancé, L. (2009). A motivational model of performance in the sport domain. European Journal of Sport Science, 9(3), 151-158. doi:10.1080/17461390902736793

Guay, F., Mageau, G. A., \& Vallerand, R. J. (2003). On the hierarchical structure of self-determined motivation: A test of top-down, bottom-up, reciprocal, and horizontal effects. Personality and Social Psychology Bulletin, 29(8), 992-1004. doi: 10.1177/0146167203253297

Guay, F., Vallerand, R. J., \& Blanchard, C. (2000). On the assessment of situational intrinsic and extrinsic motivation: The Situational Motivation Scale (SIMS). Motivation and Emotion, 24(3), 175-213. doi:10.1023/A:1005614228250

Han, J. (2013). Understanding second-hand retailing: $A$ resource based perspective of best practices leading to business success. Unpublished master's thesis, Iowa State University, IA, USA.

Hankin, A. (2016, January 20). Thrifting on the rise, especially in college. The State News, Retrieved from http://statenews.com/article/2016/01/thriftingtrend-is-on-the-rise

Horne, S. (2000). The charity shop: Purpose and change. International Journal of Nonprofit and Voluntary Sector Marketing, 5(2), 113-124. doi:10. 1002/nvsm.104

Hyllegard, K. H., Ogle, J. P., \& Dunbar, B. H. (2006). The influence of consumer identity on perceptions of store atmospherics and store patronage at a spectacular and sustainable retail site. Clothing and Textiles Research Journal, 24(4), 316-334. doi:10.1177/0887302X06293021

Lastovicka, J. L., Bettencourt, L. A., Hughner, R. S., 
\& Kuntze, R. J. (1999). Lifestyle of the tight and frugal: Theory and measurement. Journal of Consumer Research, 26(1), 85-98. doi:10.1086/209552

Maehr, M. L., \& Braskamp, L. A. (1986). The motivation factor: A theory of personal investment. Lexington, MA: Lexington Books.

Mallett, C., Kawabata, M., Newcombe, P., Otero-Forero, A., \& Jackson, S. (2007). Sport motivation scale6 (SMS-6): A revised six-factor sport motivation scale. Psychology of Sport and Exercise, 8(5), 600-614. doi:10.1016/j.psychsport.2006.12.005

Minton, A. P., \& Rose, R. L. (1997). The effects of environmental concern on environmentally friendly consumer behavior: An exploratory study. Journal of Business Research, 40(1), 37-48. doi:10. 1016/S0148-2963(96)00209-3

Mitchell, T. R. (1982). Motivation: New directions for theory, research, and practice. Academy of Management Review, 7(1), 80-88. doi:10.5465/AMR. 1982.4285467

Parsons, T. (1964). Social structure and personality. New York: Free Press.

Pelletier, L. G. (2002). A motivational analysis of selfdetermination for pro-environmental behaviors. In E. L. Deci, \& R. M. Ryan (Eds.), Handbook of self-determination research (pp. 205-232). Rochester, NY: The University of Rochester Press.

Pepper, M., Jackson, T., \& Uzzell, D. (2009). An examination of the values that motivate socially conscious and frugal consumer behaviours. International Journal of Consumer Studies, 33(2), 126-136. doi:10.1111/j.1470-6431.2009.00753.x

PESTLE (Political, Economic, Social, Technological, Legal and Environmental) Country Analysis Report: South Korea. (2016). Retrieved from https://store. marketline.com/report/ml00002-027-south-korea-i n-depth-pestle-insights

Reeger, J. (2005, November 26). Thrift stores are a growing presence. Pittsburg Tribune-Review, Retrieved November 26, 2010 from http://www. pittsburghlive.com/x/pittsburghtrib/s_398211.html
Reiss, S. (2012). Intrinsic and extrinsic motivation. Teaching of Psychology, 39(2), 152-156. doi:10. 1177/0098628312437704

Roux, D. (2006). Am I what I wear? An exploratory study of symbolic meanings associated with secondhand clothing. Advances in Consumer Research, 33, 29-35.

Ryan, R. M., \& Deci, E. L. (2000). Self-determination theory and the facilitation of intrinsic motivation, social development, and well-being. American Psychologist, 55(1), 68-78. doi:10.1037/0003-066X. 55.1 .68

Ryan, R. M., \& Deci, E. L. (2002). Overview of selfdetermination theory: An organismic dialectical perspective. In E. L. Deci., \& R. M. Ryan (Eds.), Handbook of self-determination research (pp. 333). Rochester, NY: The University of Rochester Press.

Shim, S. (1995). Environmentalism and consumers' clothing disposal patterns: An exploratory study. Clothing and Textiles Research Journal, 13(1), 38-48. doi:10.1177/0887302X9501300105

Vallerand, R. J. (2000). Deci and Ryan's self-determination theory: A view from the hierarchical model of intrinsic and extrinsic motivation. Psychological Inquiry, 11(4), 312-318.

Vlachopoulos, S. P., Karageorghis, C. I., \& Terry, P. C. (2000). Motivation profiles in sport: A selfdetermination theory perspective. Research Quarterly for Exercise and Sport, 71(4), 387-397. doi: 10.1080/02701367.2000.10608921

Ward, M. J. (1988). The many facets of self-determination. NICHCY Transition Summary: National Information Center for Children and Youth with Disabilities, 5, 2-3.

Wherry, F. F. (2008). The social characterization of price: The fool, the faithful, the frivolous, and the frugal. Sociological Theory, 26(4), 363-379. doi:10.1111/j.1467-9558.2008.00334.x

Yavas, U., \& Riecken, G. (1981). Heavy, medium, light shoppers and nonshoppers of a used merchandise 
outlet. Journal of Business Research, 9(3), 243253. doi:10.1016/0148-2963(81)90019-9

Yim, M. Y.-C., Yoo, S.-C., Sauer, P. L., \& Seo, J. H. (2014). Hedonic shopping motivation and co- shopper influence on utilitarian grocery shopping in superstores. Journal of the Academy of Marketing Science, 42(5), 528-544. doi:10.1007/s11747013-0357-2 